\title{
Serial maternal plasma concentrations of progesterone and estradiol during the morning, the afternoon and at night throughout normal pregnancy in the cynomolgus macaque
}

\author{
D.C. Dang ${ }^{1}$, G. Hidden ${ }^{2}$ and P. Rombauts ${ }^{3}$ \\ 1 INSERM, Unité 262,123 boulevard de Port-Royal, F-75674, Paris, Cedex 14; \\ 2 UER Biomédicale, laboratoire d'anatomie, F-75270, Paris; \\ 3 INRA, station de physiologie animale, F-78350, Jouy-en-Josas, France
}

(received 13 October 1988, accepted 21 June1989)

\begin{abstract}
Summary - Total progesterone (P4) and estradiol (E2) were determined in plasma from 10 pregnant cynomolgus macaques, Macaca fascicularis. A non-invasive blood collection technique utilizing a squeeze-cage and a catheter fixed momentarily in the brachial or saphenous vein allowed a 10-min serial blood sampling (SBS) for $3 \mathrm{~h}$ in the morning, the afternoon or at night at $30,50,70$, $90,110,130,150$ and 165 days of pregnancy and on the day after delivery, without modifying gestation length or damaging fetal health. During an SBS session, extensive fluctuations of high P4 levels (>10 $\mathrm{ng} / \mathrm{ml}$ ) were sometimes observed and infrequent pulses might occur, while E2 levels fluctuated only slightly but increased progressively. It is concluded that, even with the SBS method, individual differences in hormone patterns still occur throughout pregnancy. We suggest that a single daily P4 or E2 determination is not an accurate indicator of pregnancy normality.
\end{abstract}

macaque - pregnancy — parturition - progesterone - estradiol - pulses

Résumé - Concentrations sériées de progestérone et d'œstradiol dans le plasma maternel lors du matin, de l'après-midi ou de la nuit au cours de la gestation normale chez la guenon macaque cynomolgue. Nous avons voulu voir si la différence fréquemment observée d'allure des courbes individuelles d'évolution, au cours de la gestation, du taux sanguin maternel périphérique de progestérone (P4) et d'œestradiol (E2) était due à l'existence possible de pulses importants du taux de ces hormones à différents moments de la journée.

Dix femelles macaques cynomolgues, Macaca fascicularis, gestantes, immobilisées dans une cage de contention, ont été soumises à des séries successives de prélèvements sanguins à intervalle de 10-15 min pendant 1-3 h, soit le matin, soit l'après-midi ou pendant la nuit, à divers stades de la gestation $(30,50,70,90,110,130,150,165$ j) et le lendemain de la parturition. Ceci n'a pas modifié la durée de gestation, ni le poids corporel ou l'état de santé des nouveau-nés. Lors d'une séance de prélèvements sériés, indépendamment du moment de la journée, de grandes fluctuations du taux de progestérone dépassant $10 \mathrm{ng} / \mathrm{m} /$ sont observées tandis que les taux 
d'œstradiol augmentent progressivement sans présenter de grandes fluctuations. On ne connait pas les mécanismes physiologiques qui régulent la sécrétion de ces hormones stérö̈diennes. Ces résultats montrent aussi des différences interindividuelles importantes de profil de sécrétion de la progestérone au cours de la gestation, dues probablement à l'existence des pulses de sécrétion souvent détectés. Cependant les courbes moyennes de progestérone et d'cestradiol pour l'ensemble ressemblent à celles déjà observées par d'autres auteurs. Ce travail montre qu'une seule détermination quotidienne de ces hormones n'est pas un indicateur suffisant de la normalité de la gestation du macaque cynomolgue.

macaque - gestation - parturition - progestérone - cestradiol - pulse

\section{INTRODUCTION}

Maternal blood progesterone (P4) and 17 $\beta$-estradiol (E2) determinations are used in obstetrical practice to assert or confirm gestation normality since these hormones are secreted abundantly throughout pregnancy. However, it is acknowledged that during normal pregnancy of most mammals, the patterns of the concentrations of these hormones vary widely between individuals. Consequently, mean ( \pm SEM) values are given in most studies.

The purpose of this study was to ascertain whether the individual pattern differences also observed in pregnant macaque monkeys (Hodgen et al., 1972; Stabenfeldt and Hendrickx, 1972, 1973; Bosu et al., 1973) were due to variability in the concentrations of P4 and E2, to the time of blood sampling, or to the occurrence of hormone pulse. Several 10-15-min serial blood samplings for $1-3 \mathrm{~h}$ in the morning, the afternoon and at night were attempted in cynomolgus macaque, Macaca fascicularis, throughout pregnancy and after parturition. Morever, although the rhesus monkey, Macaca mulatta, has been used extensively in research on pregnancy in nonhuman primates, only a limited number of studies have been carried out on the cynomolgus macaque (Stabenfeldt and Hendrickx, 1973; Hodgen et al., 1977).

\section{MATERIALS AND METHODS}

\section{Animals}

Ten pregnant laboratory-born cynomolgus monkeys, Macaca fascicularis, ranging in age from 5.7-11.2 yr were used. All the animals had had normal previous pregnancies and had given birth to healthy offspring. They were timemated during 24-h cohabitation with a male on the 12th day of the menstrual cycle and pregnancy was confirmed by manual palpation. The animals were housed in individual cages under natural photoperiod in Paris (France) and under the laboratory conditions described elsewere (Dang, 1977).

\section{Serial blood sampling (SBS)}

The animals were restrained in a squeezecage, $70 \times 50 \times 60 \mathrm{~cm}(L, I, h)$, near their home cage. Before the experiments started, they had been acclimated to the squeeze-cage situation and to the investigators for daily routine examination of menstruation. The arm or leg of the restrained animal was immobilized to prevent removal of the catheter. A $0.6-\mathrm{mm}$ external diameter needle connected to a $30-\mathrm{cm}$ catheter was introduced in a brachial or saphenous vein, enabling continuous with drawal of blood in a sterile heparinized syringe. Catheter patency was assured between serial bleeding intervals by a sterile heparinized normal saline solution which was drawn off each time so that the animal was not 
heparinized during the entire experiment. A 2.5-ml blood sample (sometimes less) was withdrawn at 10 - or $15-\mathrm{min}$ intervals for $3 \mathrm{~h}$ beginning at $9.30,15.00$ or $21.00 \mathrm{~h}$. During the night, the monkey room was not lighted. Blood samples were centrifuged and the plasma stored at $-20^{\circ} \mathrm{C}$ until RIAs were performed. Blood cells were immediately resuspended in a sterile physiological saline solution and returned to the maternal circulation at $1-\mathrm{h}$ intervals. SBSs were carried out at around days $30,50,70,90,110,130,150$, and 165 of gestation and the day after parturition. Throughout pregnancy, 4 animals were subjected to SBS alternately in the morning and at night, 2 animals in the morning only, 3 animals in the afternoon and one at night.

\section{Plasma P4 and E2 determinations}

Plasma P4 and E2 concentrations were determined by radioimmunoassay using specific antisera developed against P4-11 $\alpha$ hemisuccinate-bovine serum albumin and E26-carboxy-methoxime-bovine serum albumin. The cross-reactivity of these antisera has been reported elsewhere (Dray et al., 1971; Gérard et al., 1979); the P4 antiserum cross-reacts $7.5 \%$ with $5 \alpha$-pregnane-3,20-dione and desoxycorticosterone, and $<1 \%$ with other steroids.

A 200- $\mu$ l plasma sample was required. Extraction was carried out with hexane for P4 and dichloromethane for E2. Duplicate aliquots were assayed without chromatography. Free and bound steroids were separated by dextrancoated charcoal after one-night incubation at $4^{\circ} \mathrm{C}$. The sensitivity of the assay was $5 \mathrm{pg}$ and $1 \mathrm{pg}$ per tube for P4 and E2 respectively. The coefficient of variation, calculated from the values of the mixed plasmas of the animals at various pregnancy stages, were $4.1 \%(n=20)$ and $3.3 \%(n=10)$ for inter- and intraassay error, respectively, at $4 \mathrm{ng} / \mathrm{ml} \mathrm{P} 4$ concentration, and $10.5 \%(n=12)$ and $4.3 \%(n=10)$ at 30 $\mathrm{ng} / \mathrm{ml}$ P4 concentration. They were $5.0 \%(n=$ $17)$ and $2.4 \%(n=10)$ at an E2 concentration of $320 \mathrm{pg} / \mathrm{ml}$, and $6.1 \%(n=12)$ and $3.9 \%$ $(n=10)$ at a concentration of $2300 \mathrm{pg} / \mathrm{ml}$. More than 16 assay series were done, each with 60 samples plus 3 control samples, one obtained from a mixed plasma and the two others from 2 castrated male and female adults. All samples from an SBS session were run in the same assay series. Many SBS session samples were reassayed to confirm the unexpected results.

\section{Hormone pulse detection}

Hormone pulses were identified by subjective criteria derived from visual inspection of the graph data and defined as any elevation in plasma hormone levels which exceeded $20 \%$ ( $>3 X$ intraassay CV) of the preceding nadir and sustained over 3 sampling periods (Ellinwood et al., 1984).

\section{RESULTS}

The technique of frequent SBSs throughout macaque pregnancy did not significantly $(P>0.05)$ modify either the normal gestation length (167.5 \pm 1.5 vs $166.8 \pm 1.0$ days) or the newborn weight $(369 \pm 23$ vs $387 \pm 29 \mathrm{~g})$. All animals delivered vaginally and the offspring were healthy at 6 months of age.

Individual plasma concentrations of $\mathrm{P} 4$ and E2 during SBS sessions throughout pregnancy and after parturition are shown for 4 representative animals in Figures 1 and 2. Concentrations of $\mathrm{P4}>10 \mathrm{ng} / \mathrm{ml}$ flucturated greatly during $3 \mathrm{~h}$ of SBS without displaying any clear pattern. These fluctuations occurred in the morning as well as in the afternoon or at night. In contrast to P4, concentrations of E2 did not exhibit noticeable fluctuations but a progressive increase from the first to the last sample of the series was often observed wether SBS was carried out in the morning, the afternoon or at night. 
According to the conventional criteria of hormone pulse identification during SBS sessions and in contrast to E2, P4 pulses were detected throughout the entire period of the experiment (Figs 1,2). The pulse number varied from $0-3$ pulses per SBS session. Approximately $41 \%$ of SBS sessions performed in the morning as well as in the afternoon or at night $\left(\right.$ chi $\left.^{2}=3.46 ; P>0.05\right)$ exhibited
1-3 pulses which occurred at any determined hormone level > $1 \mathrm{ng} / \mathrm{ml}$. Between days 30-90 of pregnancy, this percentage was less than from day 110 to term $\left(24.1 \%\right.$ vs $50.0 \%$; chi $^{2}=3.84 ; P<$ $0.05)$ or than after parturition $(54.5 \%)$.

The patterns of mean P4 and E2 levels throughout pregnancy and for each SBS session differed according to the individual (Table l). At day 90 of

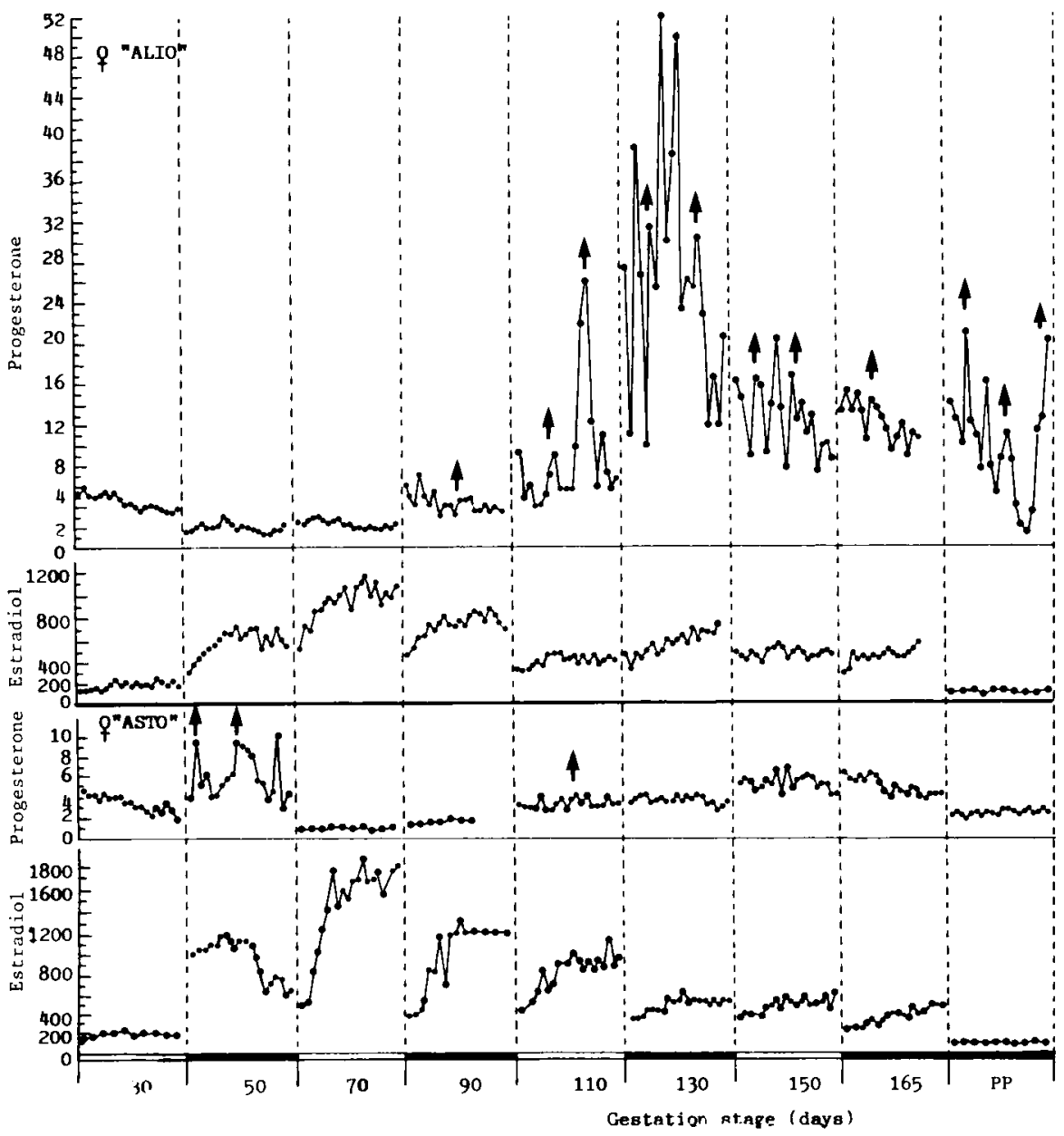

Fig. 1. Changes in plasma concentrations of progesterone $(\mathrm{ng} / \mathrm{ml})$ and estradiol $(\mathrm{pg} / \mathrm{ml})$ in each serial blood sampling sessions during pregnancy and after parturition (PP) in 2 animals, ALIO and ASTO. Bleeding sessions carried out in the morning are denoted by white bars, bleeding sessions carried out at night by black bars and hormone pulses by arrows. 


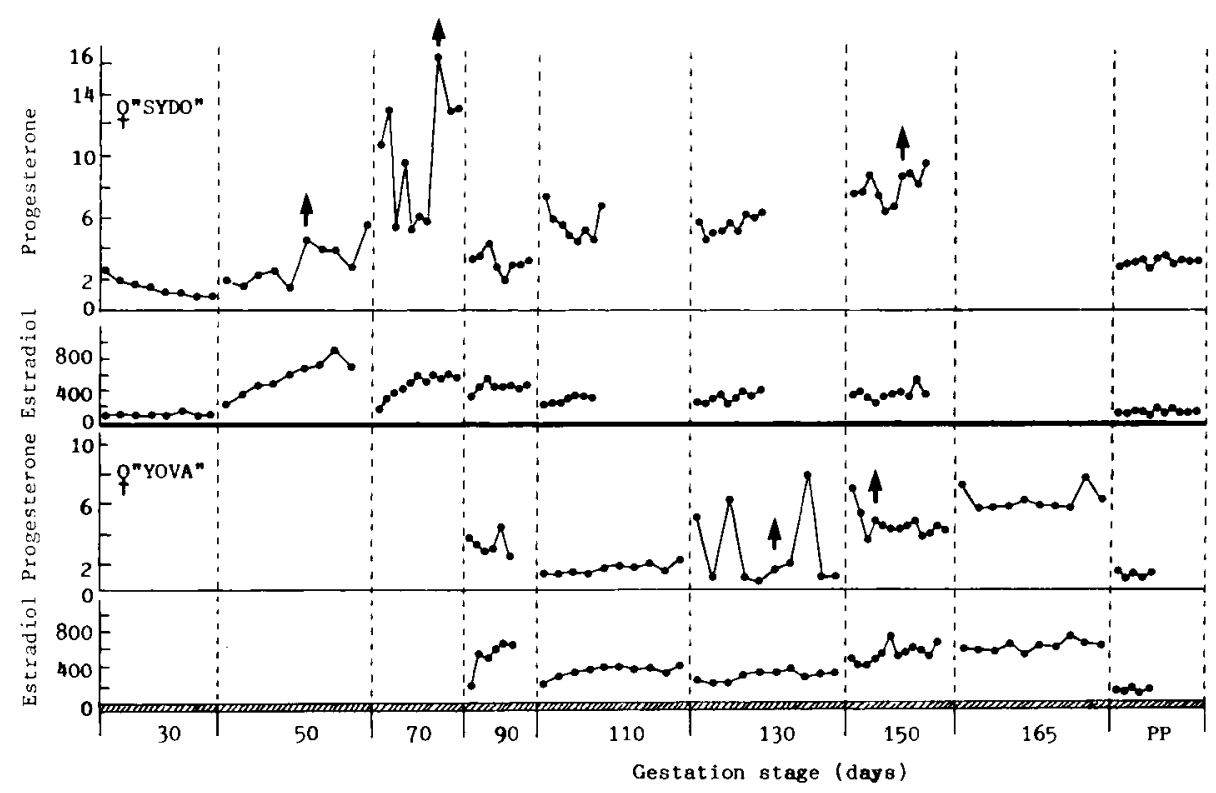

Fig. 2. Changes in plasma concentrations of progesterone $(\mathrm{ng} / \mathrm{ml})$ and estradiol $(\mathrm{pg} / \mathrm{ml})$ at each serial blood sampling carried out in the afternoon during pregnancy and after parturition (PP) in 2 animals, SYDO and YOVA. Hormone pulses are denoted by arrows.

pregnancy, the mean $\mathrm{P} 4$ level remained $<5 \mathrm{ng} / \mathrm{ml}$ in all animals. Between days $30-70$ it peaked at $6-10 \mathrm{ng} / \mathrm{ml}$ in $3-4$ animals, while from day 110 to the end of pregnancy it exceeded $12 \mathrm{ng} / \mathrm{ml}$ in 3 animals. After parturition, it fell in all the animals except one female which probably had not yet expelled the placenta. Individual patterns of mean E2 level were less dissimilar than for P4. Low levels were observed in all animals at $\approx$ day 30 , and high levels at day 70 in at least 5 animals. After delivery, all animals exhibited a low E2 level. In no animal were mean P4 and E2 concentrations correlated before day 150, but a significant correlation $(r=0.66, n=17 ; P$ $<0.05$ ) was observed from that stage to the end of gestation.

When overall means were considered, clear patterns of P4 and E2 concen- trations were observed throughout pregnancy and after parturition in cynomolgus macaques (Fig. 3). The P4 level decreased slowly from days 30-90, and then increased gradually towards the

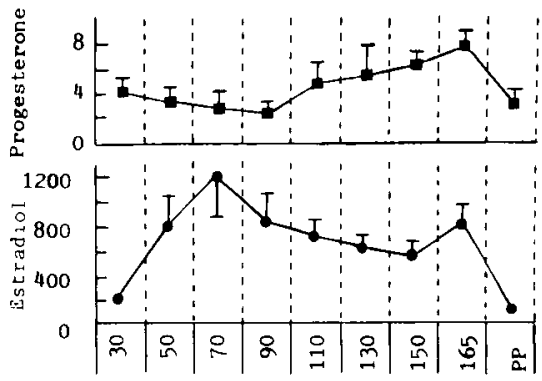

Gestation stage (days)

Fig. 3. Changes in mean ( \pm SEM) concentrations of progesterone $(\mathrm{ng} / \mathrm{ml})$ and estradiol $(\mathrm{pg} / \mathrm{ml})$ for all animals $(n=10)$ during pregnancy and after parturition (PP). 


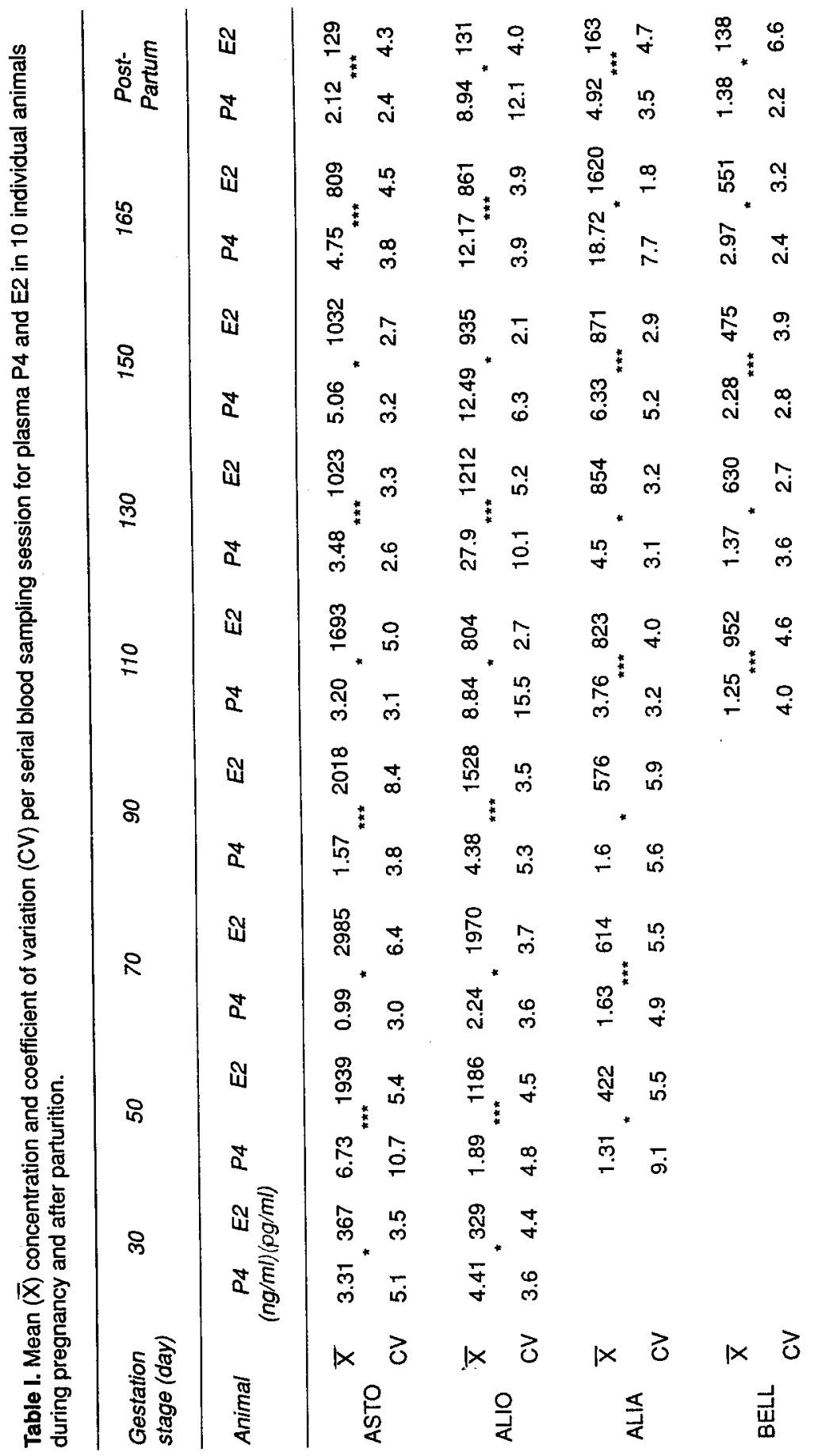




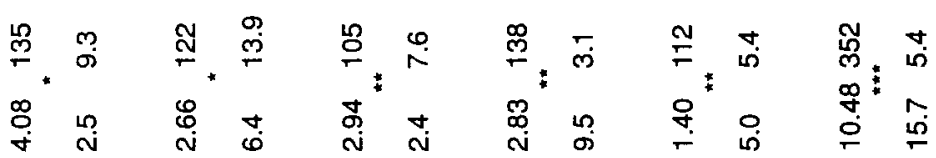

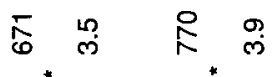

ชั

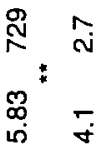

茼

\&

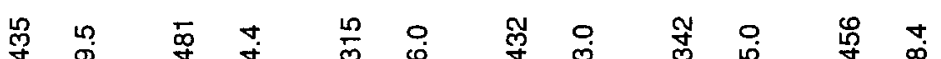

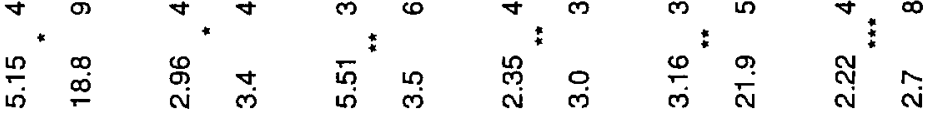

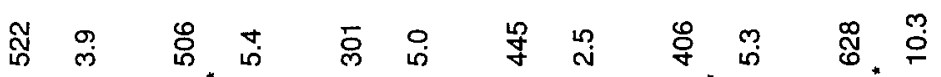

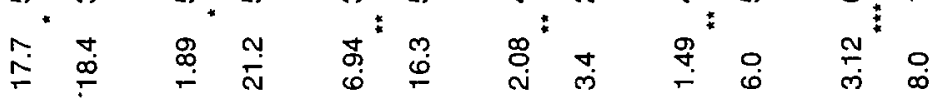

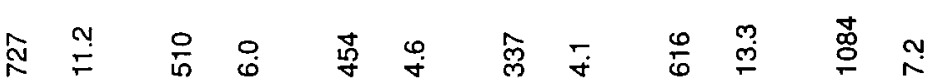

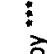

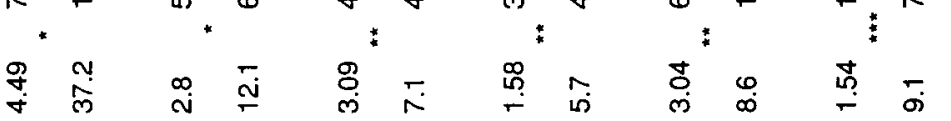

ํ.

苞

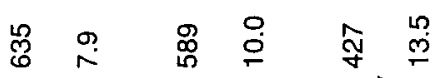

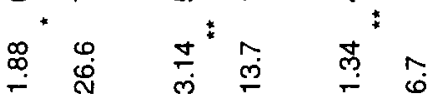

$\stackrel{\mathscr{I}}{\stackrel{\infty}{\infty}+\infty}$

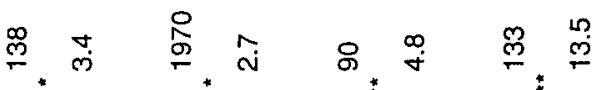

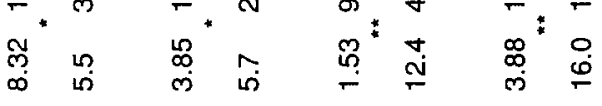

กิ

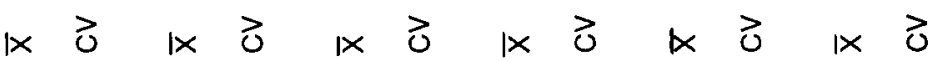
岳 莺

ì

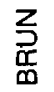

๖

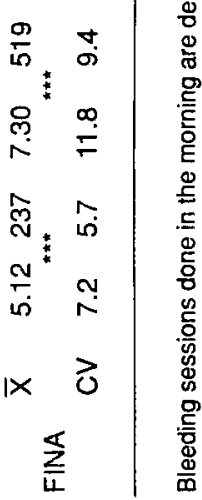


end of term and dropped after delivery. The E2 level increased exceedingly from day 30 to 70 , decreased progressively till day 150 , increased slightly at the end of term, and finally dropped after delivery.

\section{DISCUSSION}

Our technique of frequent maternal serial blood sampling throughout pregnancy, although somewhat stressful, neither modified gestation length nor damaged fetal health. This success was probably due to the fact that the animals were laboratory-born and familiar with the experimental situation. The tethering system (Bryant, 1980; McNamee et al., 1984; Sopelak and Hodgen, 1984; Ducsay et al., 1988) was also helpful, but might be difficult to use during the entire pregnancy of the same individual. The plasma volume withdrawn, however, remains a limiting factor.

This work was not planned to evidence a circadian rhythm of plasma P4 and E2 in the pregnant cynomolgus monkey, as already observed in rhesus monkeys (Challis et al., 1980; Hess et al., 1981; Walsh et al., 1984). Nevertheless, our analysis of results did not reveal a circadian rhythm of those two hormone concentrations. This discrepancy might be explained by our different method of serial blood sampling.

When P4 levels were high, extensive fluctuations occurred during an SBS session in the morning as well as in the afternoon or at night. This could not be an artifact of hormone determination as all samples from at least 3 SBS sessions were run in the same assay series; furthermore, many suspected samples were reassayed to confirm unusual data and the control levels of castrated male and female animals were practically null and that of the mixed plasma nearly the same in each assay series. Therefore, these fluctuations must serve to activate secretory processes. In contrast to results obtained for $\mathrm{P} 4$, no extensive fluctuations of E2 levels were observed during a SBS session. Progressive increases, however, were noted. These increases, arising from an alteration in the rate of synthesis and/or secretion of the fetoplacental unit, could not be explained. They might be related to stress in the animal while immobilized, although we have checked that our E2 antiserum did not cross-react with cortisol.

Based on the above conventional criteria of hormone pulse determination, pulses occurred for P4 and not for E2, and more frequently towards the end than between days 30 and 90 of pregnancy or after parturition. This observation might be related to the increasing levels of $\mathrm{P} 4$ secreted mostly by the placenta while at post-partum, pulse frequency was controlled by the ovary. In the cow, pulses of P4 occurring at midgestation are thought to be the result of stimulation by pulses of $\mathrm{FSH}$ as pulses of $\mathrm{LH}$ are abolished (Schallenberger et al., 1983). In the baboon, it was suggested that estrogen regulates progesterone formation during mid or late pregnancy (Albrecht, 1980). In the macaque, we did not find a relation between $\mathrm{P} 4$ and E2 plasma levels before day 150 of pregnancy, and concentrations of chorionic gonadotropin were undetectable after day 40 of pregnancy and lactation (Hodgen et al., 1972; Walsh et al., 1977; Chandrashekar et al., 1980; Yoshida, 1983); immunoreactive FSH concentrations may (Chandrashekar et al., 1987) or may not (Yoshida, 1983) fluctuate. Consequently, the mechanisms that 
regulate $\mathrm{P} 4$ and $\mathrm{E} 2$ fluctuation levels in pregnant macaque remain unknown.

Even with $10 \mathrm{~min}$ SBS for $3 \mathrm{~h}$, individual pattern differences persisted in P4 and E2 levels throughout pregnancy. Further experiments are necessary to answer the questions regarding possible pattern changes during successive gestations in the same individual.

It has been suggested that P4 withdrawal (Bedford et al., 1972; Challis and Manning, 1978) or increase in estrogen levels in peripheral maternal plasma (Bosu et al., 1973; Atkinson et al., 1975; Sholl et al., 1979; Walsh et al., 1979), are important factors in the events associated with the initiation of parturition, but some animals in this study exhibited an increase in $\mathrm{P} 4$ level followed by a decrease, or a considerable elevation in E2 level at about day 70 of gestation, even though no animal delivered prematurely. Furthermore, the administration of estradiol benzoate to pregnant rhesus monkey at mid-gestation, while resulting in an increase in circulating E2 concentration, did not damage the fetus which was born healthy at normal term (Weiss et al., 1976). It is possible that a low critical P4 level or high critical E2 level has to be sustained for a certain length of time to promote the onset of parturition; our SBS sessions were not seriated enough for this possibility to be verified. Moreover, as hormone fluctuations occur frequently, a single daily P4 or E2 determination would be unlikely to be an accurate indicator of pregnancy normality in obstetric practice.

Some animals exhibited high P4 levels at certain stages of pregnancy. With this exception, the general P4 pattern reported here agrees with that of earlier studies (Stabenfeldt and Hendrickx, 1973; Hodgen et al., 1977). Also in agreement with previous work, P4 produced mainly by the placenta during the latter half of pregnancy (Weiss et al., 1976; Chandrashekar et al., 1980; Walsh, 1985) did not decline to undetectable levels in the $16 \mathrm{~h}$ following delivery. Accordingly, this P4 must have been secreted by the corpus luteum (Hodgen et al., 1977). The substantial increase in plasma E2 in many animals at about 70 days of gestation and its decrease thereafter contrast with the situation reported in earlier studies in pregnant macaques (Hodgen et al., 1972, 1977; Chandrashekar et al., 1987) but confirm other reports (Atkinson et al., 1975; Walsh et al., 1979). Moreover, this E2 originates partially from the ovary containing the corpus luteum, as E2 concentrations are higher in the uteroovarian vein than in the uterine vein plasma (Walsh et al., 1979). Consistent with previous reports (Hodgen et al., 1972: Weiss et al., 1976; Sholl et al., 1979; Walsh et al., 1979; Chandrashekar et al., 1987), E2 levels fell abruptly after delivery.

In conclusion, throughout pregnancy and at post-partum in cynomolgus macaques immobilized in a squeeze-cage for $3 \mathrm{~h}$, maternal peripheral P4 levels may fluctuate greatly while E2 levels may increase progressively. The mechanisms that regulate these hormonal fluctuations remain to be determined.

\section{ACKNOWLEGMENTS}

We would like to thank M.-C. Levasseur and M. Courot for valuable discussions, D. Low and B. Valpreda for correcting and typing the manuscript and G. Aphecix for his help in breeding the animals. 


\section{REFERENCES}

Albrecht E.B. (1980) A role for estrogen in progesterone production during baboon pregnancy. Am. J. Obstet. Gynecol. 136, 569-574

Atkinson L.E., Hotchkiss J., Fritz G.R., Surve A.H., Neill J.D. \& Knobil E. (1975) Circulating levels of steroids and chorionic gonatropin during pregnancy in the rhesus monkey, with special attention to the rescue of the corpus luteum in early pregnancy. Biol. Reprod. 12, 335-345

Bedford W.T.K., Challis J.R.G., Harrisson F.A. \& Heap R.B. (1972) The role of œstrogens and progesterone in the onset of parturition in various species. J. Reprod. Fert. suppl. 16, 123

Bosu W.T.K., Johanson E.D.B. \& Gemzell C. (1973) Peripheral plasma levels of œestrogens, progesterone and $17 \alpha$-hydroxyprogesterone during gestation in the rhesus monkey. Acta Endocrinol. (Kbh) 14, 348-360

Bryant J.M. (1980) Vest and tethering system to accomodate catheters and a temperature monitor for nonhuman primates. Lab. Anim. Sci. 30, 706-708

Challis J.R.G. \& Manning F.A. (1978) Control of parturition in subhuman primates. Semin. Perinatol. 3, 247-260

Challis J.R.G., Socol M., Murata Y., Manning F.A. \& Martin C.B. Jr. (1980) Diurnal variations in maternal and fetal steroids in pregnant rhesus monkeys. Endocrinology 106, 12831288

Chandrashekar V.J., Wolf R.C., Dierschke D.J., Sholl S.A., Bridson W.E. \& Clark J.R. (1980) Serum progesterone and corpus luteum function in pregnant pigtailed monkeys (Macaca nemestrina). Steroids 36, 483-495

Chandrashekar V.J., Dierschke D.J. \& Wolf R.C. (1987) Excessive ovarian follicular development in pregnant pigtailed macaques (Macaca nemestrina). Am. J. Primatol. 13, 145153

Dang D.C. (1977) Absence of seasonal variation in the length of the menstrual cycle and the fertility of the crab-eating macaque (Macaca fascicularis) raised under natural daylight ratio. Ann. Biol. Anim. Bioch. Biophys. 17, 1-17

Dray F., Terqui M., Desfosses B., Chauffournier J.M., Mowszowiz I., Kann D., Rombauts P. \&
Jayle M.F. (1971) Propriété d'immunsérum anti$17 \beta$-œstradiol obtenus chez différentes espèces animales avec l'antigène 17ß-œstradiol-6-0-carboxyméthoxime-sérum albumine de bœuf. CR Acad. Sci. Paris (Sér. D) 173, 23802383

Ducsay C.A., Cook M.J. \& Novy M.J. (1988) Simplified vest and tether system for maintenance of chronically catheterized pregnant rhesus monkeys. Lab. Anim. Sci. 38, 343-344

Ellinwood W., Norman R.L. \& Spies H.G. (1984) Changing frequency of pulsatile luteinizing hormone and progesterone secretion during the luteal phase of the menstrual cycle of rhesus monkeys. Biol. Reprod. 31, 714-722

Gérard M., Ménézo Y., Rombauts P., Szollosi D. \& Thibault C. (1979) In vitro studies of oocyte maturation and follicular metabolism in the pig. Ann. Biol. Anim. Biochim. Biophys. 19, 1521-1535

Hess D.L., Spies H.G. \& Hendrickx A.G. (1981) Diurnal steroid patterns during gestation in the rhesus macaque : onset, daily variation, and the effects of dexamethasone treatment. Biol. Reprod. 24, 609-616

Hodgen G.D., Dufau M.L., Catt K.J. \& Tullner W.W. (1972) Estrogens, progesterone and chorionic gonadotropin in pregnant rhesus monkeys. Endocrinology 91, 896-900

Hodgen G.D., Stouffer R.L., Barber D.L. \& Nixon W.E (1977) Serum estradiol and progesterone during pregnancy and the status of the cropus luteum at delivery in cynomolgus monkeys (Macaca fascicularis). Steroids 30 , 295-301

McNamee G.A., Wannemacher R.W. Jr, Dinterman R.E. Jr, Rozmiar K.H \& Montrey R.D. (1984) A surgical procedure and tethering system for chronic blood sampling, infusion, and temperature monitoring in caged nonhuman primates. Lab. Anim. Sci. 34, 303-307

Shallenberger E., Rampp J. \& Walters D.L. (1983) Pulsatile progesterone secretion during midgestation in the cow even though pulsatile LH secretion is abolished. J. Anim. Sci. 51 (suppl. 1), 371

Sholl S.A., Robinson J.A. \& Wolf R.C. (1979) Estrone, 17 $\beta$-estradiol and cortisol in serum of peripartum rhesus monkeys. Endocrinology 104, 1274-1278

Sopelak V.M. \& Hodgen G.D. (1984) Techniques for research in fetal neonatal 
primates. In : Animal Models in Fetal Medicine (P.W. Nathanielsz, ed.) Perinatology Press, pp. 161-181

Stabenfeldt G.H. \& Hendrickx A.G (1972) Progesterone levels in the bonnet monkey (Macara radiata) during the menstrual cycle and pregnancy. Endocrinology 91, 614-619

Stabenfeldt G.H. \& Hendrickx A.G. (1973) Progesterone studies in the Macaca fascicularis. Endocrinology 92, 1296-1300

Walsh S.W. (1985) Regulation of progesterone and estrogen production during rhesus monkey pregnancy. In : Perinatal Endocrinology (Albrecht E. \& Pepe G.P., eds.), Perinatology Press, pp. 219-241

Walsh S.W., Wolf R.C., Meyer R.D., Aubert M.L. \& Friesen H.G. (1977) Chorionic gonadotropin, chorionic somatomammotropin and prolactine in the uterine vein and peripheral plasma in pregnant rhesus monkeys. Endocrinology 100, 851-855

Walsh S.W., Wolf R.C., Meyer R.K. \& Robinson J.A. (1979) Estrogens in the utero-ovarian, uterine, and peripheral plasma in pregnant rhesus monkeys. Biol. Reprod. 20, 606-610

Walsh S.W., Stanczyk F.Z. \& Novy M.J. (1984) Daily hormonal changes in the maternal, fetal and amniotic fluid compartments before parturition in a primate species. J. Clin. Endocr. Metab. 58, 629-639

Weiss G., Butler W.R., Hotchkiss J., Dierschke D.J. \& Knobil E. (1976) Periparturitional serum concentrations of prolactine, the gonadotropins and the gonadal hormones in the rhesus monkey. Proc. Soc. Exp. Biol. Med. 151, 113116

Yoshida T. (1983) Serum gonadotropin levels during the menstrual cycle and pregnancy in the cynomolgus monkey. Jpn J. Med. Sci. Biol. $36,231-236$ 